\title{
The Effect of Air Flow Rate on Oxygen Purity Level in Pressure Swing Adsorption Equipment with Zeolite 13x and Natural Zeolite Bayah
}

\author{
Dhimas Satria ${ }^{1 *}$, Teguh Kurniawan ${ }^{1}$, Imron Rosyadi ${ }^{1}$, Rina Lusiani ${ }^{1}$, Mekro Per- \\ mana Pinem ${ }^{1}$, Nidya Jullanar Salman ${ }^{1}$ \\ ${ }^{I}$ Mechanical Engineering Department Universitas Sultan Ageng Tirtayasa Jendral Sudirman Street Km. 3, Cilegon, \\ Banten \\ "Corresponding author. Email: dhimas@untirta.ac.id
}

\begin{abstract}
One of the oxygen generators is a Pressure Swing Adsorption (PSA) machine which is intended as a central oxygenproducing source on a smaller scale by a concentrator machine. Oxygen from the PSA device will be flowed to the patient through the terminal on the patient's bed or flowed to an oxygen cylinder as a supply or backup. Given the importance of the Pressure Swing Adsorption (PSA) machine for oxygen therapy, therefore to help purify the oxygen in the machine, zeolite assistance is needed. The methodology used in this study is an experimental method, namely by testing the air flow rate on the level of oxygen purity produced by the PSA device. By doing this research, it is expected to know the effect of air flow rate on the level of oxygen purity produced by the PSA device. With this research, it is also possible to know the optimal air flow rate to be able to produce a high level of oxygen purity. The results obtained from this study are the effect of the flow rate on the purity of oxygen produced by the PSA device, that is, if the flow rate is greater, the purity of oxygen obtained will be smaller. This is because the flow rate that is too large will cause the zeolite to decrease its ability to absorb gas faster because too much gas enters the tube so that too many molecules stick to the pores of the zeolite. The optimal flow rate to produce high oxygen purity for the PSA device used in this study is $20 \mathrm{~L} / \mathrm{min}$ for both types of adsorbents, resulting in an oxygen purity of $82 \%$ using Zeolite 13X. Meanwhile, with a mixture of Zeolite 13X and Zeolite Alam Bayah obtained a maximum purity of $73 \%$ with the same flow rate.
\end{abstract}

\section{Keywords: Zeolite, PSA, Absorption, Oxygen Purity}

\section{INTRODUCTION}

Oxygen is one of the elements contained in dry air. Living things, namely humans, need oxygen to breathe and survive, especially when oxygen needs are urgently needed, such as during the COVID-19 pandemic that attacks human respiratory organs.

One of the oxygen producers is a Pressure Swing Adsorption (PSA) machine [1] which is designated as a central oxygen-producing source on a smaller scale by a concentrator machine [2]. Oxygen from the PSA device will be flowed to the patient through the terminal on the patient's bed or flowed to an oxygen cylinder as a supply or backup [3][4][5].

Given the importance of the Pressure Swing Adsorption (PSA) machine for oxygen therapy, therefore to help purify the oxygen in the machine, zeolite assistance is needed. [6], is a natural zeolite [7][8] and synthetic zeolite [9][10]. Natural zeolite is used because it is easy to obtain, especially in the Bayah area, Banten Province [11], while the synthetic zeolite commonly used in PSA is 13X zeolite because it has a good ability to adsorb nitrogen compared to other types of synthetic zeolite.[12][13][14].This study aims to determine the effect of air flow rate on the level of oxygen purity in a pressure swing adsorption device using synthetic zeolite $13 \mathrm{X}$ and natural zeolite Bayah.

\section{METHODS}

The methodology used in this study is an experimental method [15][16], namely by testing the air flow rate on the level of oxygen purity produced by the PSA 
device. By doing this research, it is expected to know the effect of air flow rate on the level of oxygen purity produced by the PSA device. With this research, it can also be seen the optimal air flow rate to be able to produce a high level of oxygen purity. The variation used is the flow rate variation, namely $20 \mathrm{~L} / \mathrm{min}, 25 \mathrm{~L} / \mathrm{min}, 30$ $\mathrm{L} / \mathrm{min}, 35 \mathrm{~L} / \mathrm{min}, 40 \mathrm{~L} / \mathrm{min}$. And also using a variety of adsorbent media, namely $13 \mathrm{X}$ synthetic zeolite and a combination of $13 \mathrm{X}$ synthetic zeolite with Bayah natural zeolite. lows:

The tools and materials used in this study are as fol-

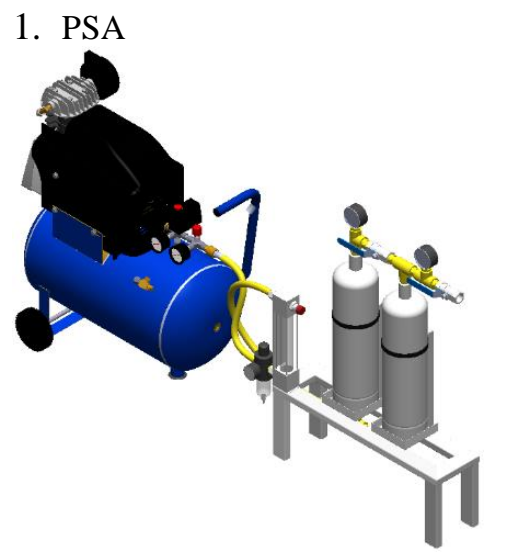

Figure 1. PSA.

The PSA used has a capacity of up to $2.5 \mathrm{~kg}$, a power source, a manual valve mechanism and a single bed type.

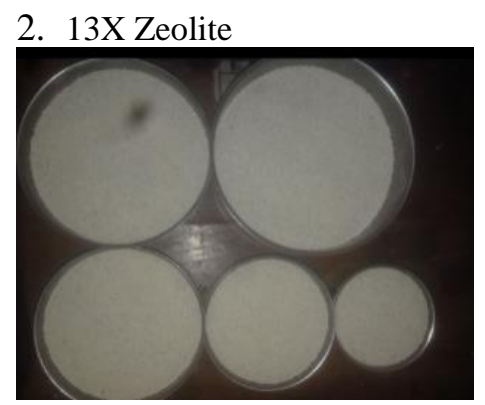

Figure 2. 13X Zeolite.

Synthetic zeolite uses $13 \mathrm{X}$ zeolite because $13 \mathrm{X}$ zeolite has a better nitrogen adsorption ability than other synthetic zeolite [12].

\section{Bayah Natural Zeolite.}

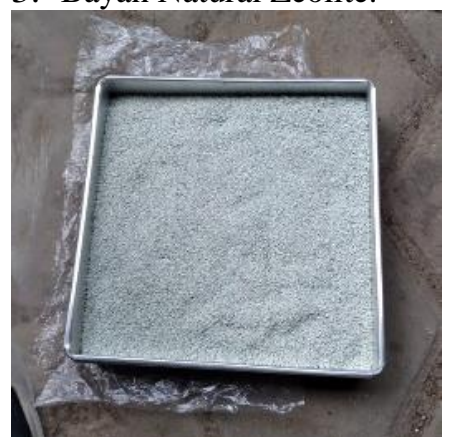

Figure 3. Bayah Natural Zeolite.

Bayah natural zeolite is used because it is easy to obtain and the price is also more affordable, so it can be used in combination with $13 \mathrm{X}$ synthetic zeolites which can function to absorb liquids that are mostly produced by the adsorption process in the PSA device.

\section{Furnace.}

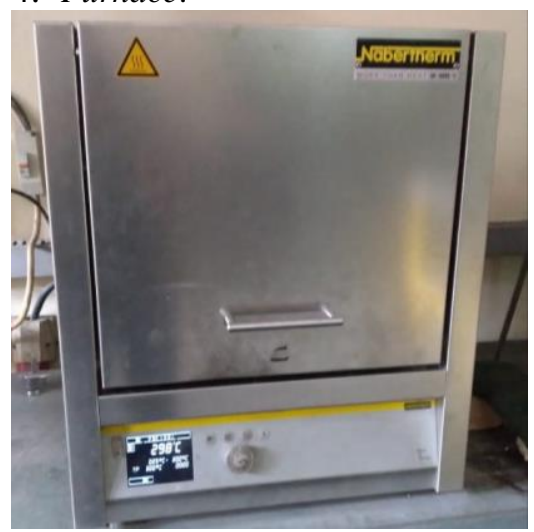

Figure 4. Furnace.

The furnace in this study was to calcinate $13 \mathrm{X}$ zeolite and Bayah natural zeolite with the calcination process temperature of $300^{\circ} \mathrm{C}$ and carried out for 60 minutes.

\section{RESULTS AND DISCUSSION}

Table 1 is the oxygen quality test data with the pressure used is 20 Psi with a variation of $13 \mathrm{X}$ zeolite adsorbent media and a combination of zeolite 13 with Bayah natural zeolite. And using flow rate variations, namely 20 $\mathrm{L} /$ minute, $25 \mathrm{~L} /$ minute, $30 \mathrm{~L} /$ minute, $35 \mathrm{~L} /$ minute and 40 $\mathrm{L} /$ minute. The results obtained are that the smaller the flow rate, the better or higher the oxygen quality level. 
Table 1.Testing Data.

\begin{tabular}{|c|c|c|c|}
\hline \multirow{2}{*}{$\begin{array}{c}\text { Times } \\
\text { (s) }\end{array}$} & \multirow[b]{2}{*}{$\begin{array}{l}\text { Flow rate } \\
\text { (L/minutes) }\end{array}$} & \multicolumn{2}{|c|}{ Concentration $\mathrm{O}_{2}(\%)$} \\
\hline & & 13X Zeolite & $\begin{array}{c}13 \mathrm{X} \text { Zeolite } \\
+ \text { ZAB }\end{array}$ \\
\hline 20 & \multirow{3}{*}{20} & 82 & 73 \\
\hline 40 & & 81 & 72 \\
\hline 60 & & 80 & 71 \\
\hline 20 & \multirow{3}{*}{25} & 80 & 71 \\
\hline 40 & & 78 & 69 \\
\hline 60 & & 76 & 67 \\
\hline 20 & \multirow{3}{*}{30} & 78 & 69 \\
\hline 40 & & 76 & 67 \\
\hline 60 & & 74 & 64 \\
\hline 20 & \multirow{3}{*}{35} & 76 & 65 \\
\hline 40 & & 73 & 62 \\
\hline 60 & & 70 & 59 \\
\hline 20 & \multirow{3}{*}{40} & 72 & 61 \\
\hline 40 & & 69 & 57 \\
\hline 60 & & 65 & 53 \\
\hline
\end{tabular}

In the adsorption process with PSA technology, not only pressure affects the level of purity of oxygen produced. In this study, what is considered is the air flow rate of the oxygen production equipment used. During the adsorption process, gas molecules that match the size of the pores of the adsorbent will enter the pores and molecules that are not suitable will pass. The flow rate can also affect the adsorption process [17].

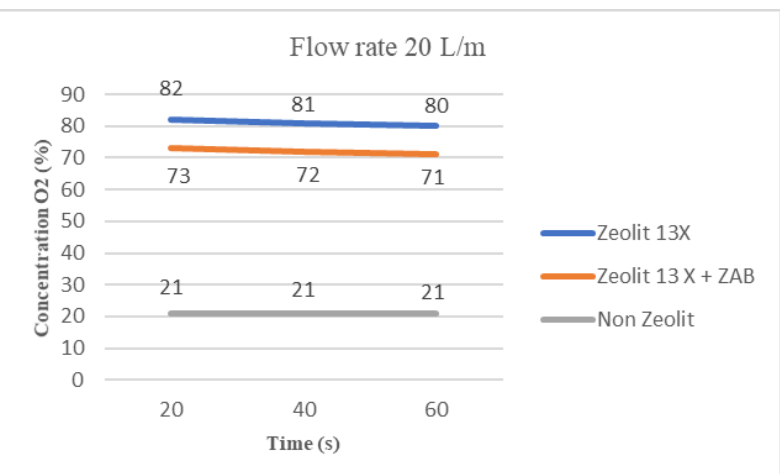

Figure 5. Oxygen Purity Graph with Flow Rate 20 $\mathrm{L} / \mathrm{min}$.
The graph in Figure 5 is the data obtained from the operation of the PSA device with a flow rate of $20 \mathrm{~L} / \mathrm{min}$. From the graph it can be concluded that: In operation for 20 seconds, it produces $82 \%$ purity us-ing Zeolite $13 \mathrm{X}$, while using a mixture of Zeolite $13 \mathrm{X}$ and Zeolite Alam Bayah produces $73 \%$ oxygen puri-ty. In operation for 40 seconds, it produces a purity of $81 \%$ using Zeolite $13 \mathrm{X}$, while using a mixture of Zeolite $13 \mathrm{X}$ and Zeolite Alam Bayah produces $72 \%$ oxygen purity. At 60 seconds of operation it produces $80 \%$ purity using Zeolite $13 \mathrm{X}$, while using a mixture of Zeolite $13 \mathrm{X}$ and Zeolite Alam Bayah produces $71 \%$ oxygen purity.

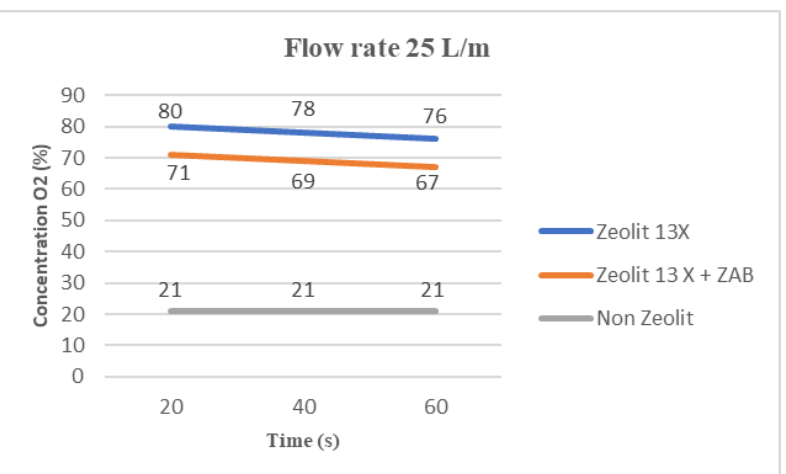

Figure 6. Oxygen Purity Graph with Flow Rate 25 $\mathrm{L} / \mathrm{min}$.

The graph in Figure 6 is the data obtained from the operation of the PSA device with a flow rate of $25 \mathrm{~L} / \mathrm{min}$. From the graph above, it can be concluded that: Operation for 20 seconds produces $80 \%$ purity using Zeolite $13 \mathrm{X}$, while using a mixture of Zeolite $13 \mathrm{X}$ and Zeolite Alam Bayah produces $71 \%$ oxygen purity. In operation for 40 seconds, it produces a puri-ty of $78 \%$ using Zeolite 13X, while using a mixture of Zeolite $13 \mathrm{X}$ and Zeolite Alam Bayah produces $69 \%$ oxygen purity. At 60 seconds of operation it produces $76 \%$ purity using Zeolite $13 \mathrm{X}$, while using a mixture of Zeolite $13 \mathrm{X}$ and Zeolite Alam Bayah produces $67 \%$ oxygen purity. 


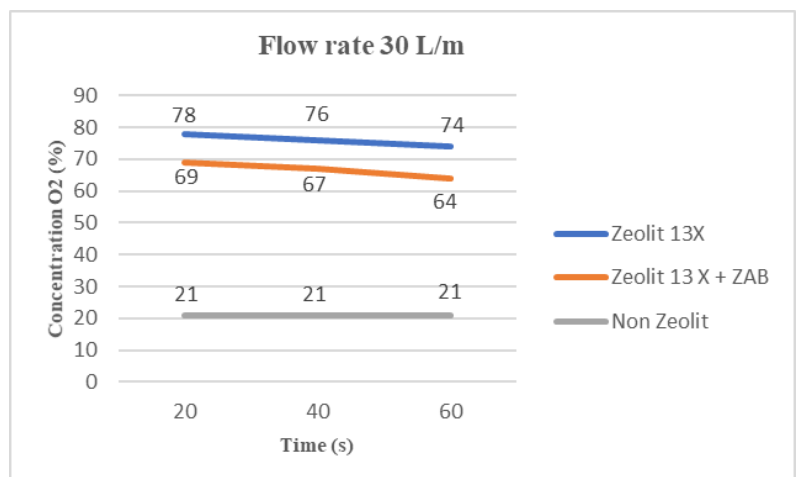

Figure 7. Oxygen Purity Graph with Flow Rate 30 $\mathrm{L} / \mathrm{min}$.

The graph in Figure 7 is the data obtained from the operation of the PSA device with a flow rate of $30 \mathrm{~L} / \mathrm{min}$. From the graph above, it can be concluded that: In operation for 20 seconds, it produces a purity of $78 \%$ using Zeolite $13 \mathrm{X}$, while using a mixture of Zeolite $13 \mathrm{X}$ and Zeolite Alam Bayah produces $69 \%$ oxygen purity. In operation for 40 seconds, it produc-es a purity of $76 \%$ using Zeolite 13X, while using a mixture of Zeolite $13 \mathrm{X}$ and Zeolite Alam Bayah pro-duces $67 \%$ oxygen purity. In operation for $60 \mathrm{sec}$-onds, it produces a purity of $74 \%$ using Zeolite $13 \mathrm{X}$, while using a mixture of Zeolite $13 \mathrm{X}$ and Zeolite Alam Bayah produces $64 \%$ oxygen purity.

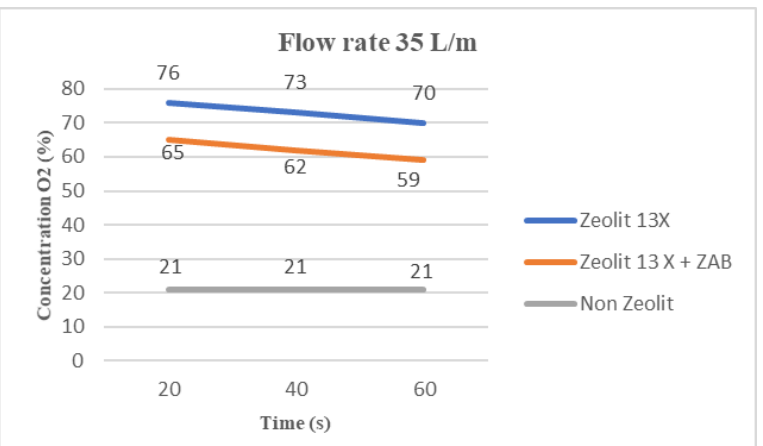

Figure 8. Oxygen Purity Graph with Flow Rate 35 $\mathrm{L} / \mathrm{min}$.

The graph in figure 8 is the data obtained from the operation of the PSA device with a flow rate of $35 \mathrm{~L} / \mathrm{min}$. From the graph above, it can be concluded that: In operation for 20 seconds, it produces a purity of $76 \%$ using Zeolite 13X, while using a mixture of Zeolite $13 \mathrm{X}$ and Zeolite Alam Bayah produces $65 \%$ oxygen purity. In operation for 40 seconds, it produc-es a purity of $73 \%$ using Zeolite $13 \mathrm{X}$, while using a mixture of Zeolite $13 \mathrm{X}$ and Zeolite Alam Bayah pro-duces $62 \%$ oxygen purity. At 60 seconds of operation it produces $70 \%$ purity using Zeo- lite $13 \mathrm{X}$, while using a mixture of Zeolite $13 \mathrm{X}$ and Zeolite Alam Bayah produces 59\% oxygen purity.

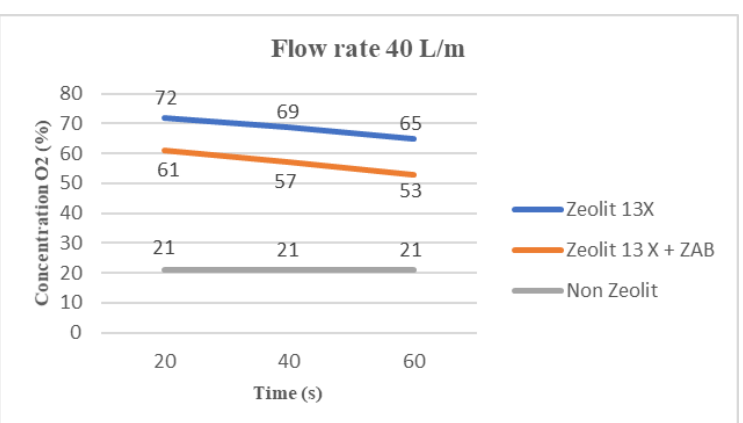

Figure 9. Oxygen Purity Graph with Flow Rate 40 $\mathrm{L} / \mathrm{min}$.

The graph in figure 9 is the data obtained from the operation of the PSA device with a flow rate of $40 \mathrm{~L} / \mathrm{min}$. From the graph above, it can be concluded that: Operation for 20 seconds produces a purity of $72 \%$ using Zeolite $13 \mathrm{X}$, while using a mixture of Zeo-lite $13 \mathrm{X}$ and Zeolite Alam Bayah produces $61 \%$ oxy-gen purity. In operation for 40 seconds, it produces $69 \%$ purity using Zeolite $13 \mathrm{X}$, while using a mixture of Zeolite $13 \mathrm{X}$ and Zeolite Alam Bayah produces $57 \%$ oxygen purity. In operation for 60 seconds, it produces a purity of $65 \%$ using Zeolite 13X, while using a mixture of Zeolite $13 \mathrm{X}$ and Zeolite Alam Bayah produces 53\% oxygen purity.

From the data above, it can be seen that the flow rate affects the oxygen content produced by the PSA device. From the data obtained, it can be seen that the greater the air flow rate on the PSA device, the faster the decrease in the level of purity produced. This is because the longer the adsorbent will experience saturation due to the fact that the pores are al-ready filled with adsorbed gas molecules and the flow rate is too large, making it difficult for gas molecules to be absorbed by the adsorbent. The large flow rate also results in less gas being adsorbed by the adsorbent. The flow rate affects the adsorption ability of the adsorbent in the adsorption column. 


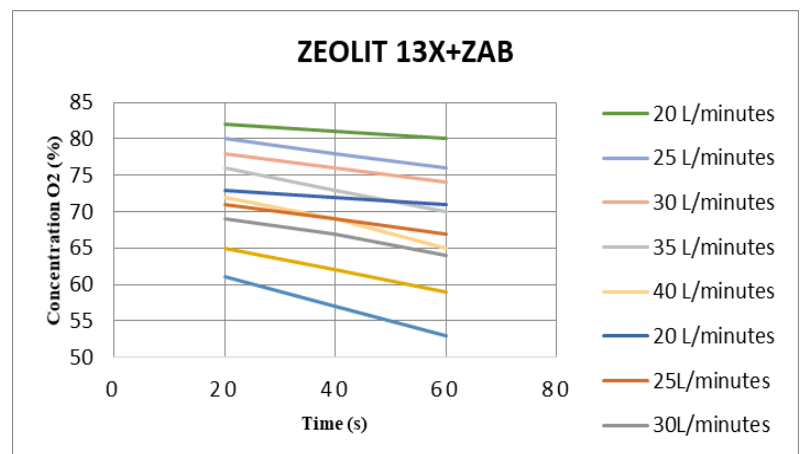

Figure 10. The Effect of Flow Rate on Oxygen Purity with Zeolite 13X.

The graph in figure 10 shows that the most op-timal flow rate to produce high purity oxygen is $20 \mathrm{~L} / \mathrm{min}$ with the highest purity of $82 \%$. While the low-est level of purity is at a flow rate of $40 \mathrm{~L} / \mathrm{min}$ with the highest purity of $73 \%$. If the greater the air flow rate used in the PSA device, the purity level of the oxygen produced will decrease. The magnitude of the flow rate also affects the saturation level of the ad-sorbent. The greater the flow rate, the faster the ad-sorbent will saturate and result in a decrease in the adsorption power of the adsorbent.

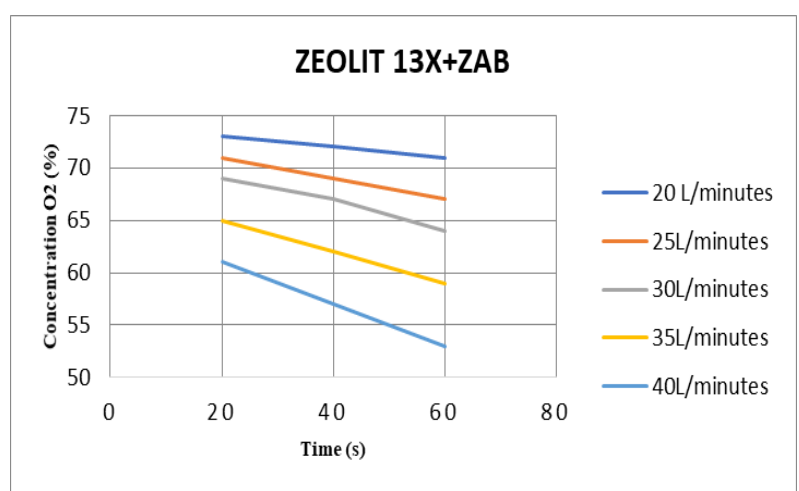

Figure 11. The Effect of Flow Rate on Oxygen Purity with Zeolite 13X and Zeolite Alam Bayah.

The graph in Figure 11 shows the difference with the previous graph, namely the graph above shows a lower level of oxygen purity than the previous graph with the highest purity level of $73 \%$ with a flow rate of $20 \mathrm{~L} / \mathrm{min}$, while the lowest purity is at a flow rate of 40 $\mathrm{L} / \mathrm{min}$. This is caused by the different types of adsorbents used. In Figure 4.7 above the type of ad-sorbent used is a mixture of Zeolite 13X with Zeolite Alam Bayah where Zeolite $13 \mathrm{X}$ is a synthetic zeolite while Zeolite Alam Bayah is a zeolite obtained direct-ly from mining in nature. From the results of the re-search above, it can also be seen that the longer the adsorption process, the saturation of the adsorbent will occur which results in a decrease in the adsorption power of the adsorbent. Therefore, the optimal flow rate in this PSA device is $20 \mathrm{~L} / \mathrm{min}$ to produce a high level of purity with a mixture of Zeolite $13 \mathrm{X}$ and Alam Bayah Zeolite as adsorbent.

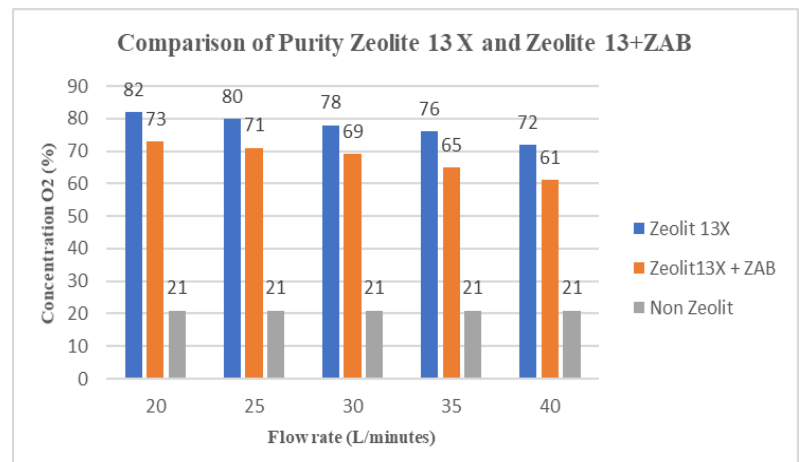

Figure 12. Comparison of Purity Zeolite $13 \mathrm{X}$ and Zeolite $13 \mathrm{X}+\mathrm{ZAB}$

From the graph in Figure 12 it can be seen that the level of purity produced using Zeolite $13 \mathrm{X}$ is greater than the mixture of Zeolite 13X and Zeolite Alam Bayah $(\mathrm{ZAB})$. In the graph above there are five variations of the flow rate used. The difference in oxygen purity is also caused by the different flow rates used. Based on the graph above, the greater the flow rate, the lower the level of purity produced. Oxygen produced by using Zeolite $13 \mathrm{X}$ adsorbent and flow rate of $20 \mathrm{~L} / \mathrm{min}$ has the highest purity of $82 \%$. If you use a mixture of Zeolite $13 \mathrm{X}$ and Zeolite Alam Bayah, a lower level of purity is produced than using Zeolite $13 \mathrm{X}$ alone. The optimal purity obtained from the mixture of the two zeolites is $73 \%$.

This research shows that Zeolite $13 \mathrm{X}$ is a suitable adsorbent material to produce oxygen with a high enough purity. Zeolite $13 \mathrm{X}$ has a higher adsorption power than Alam Bayah Zeolite, it is proven by the high purity produced. Zeolite $13 \mathrm{X}$ is generally used as an adsorbent used by oxygen-producing devices with PSA technology because the zeolite has a high ability to select and adsorb gases other than oxygen. The graph above also shows that the higher the flow rate used, the lower the purity of the oxygen produced. This is because the flow rate that is too large will cause the zeolite to decrease its ability to absorb gas faster because too much gas enters the tube so that too many molecules stick to the pores of the zeolite.

\section{CONCLUSION}

The conclusion that can be obtained from the research that has been carried out is the effect of flow rate on the purity of oxygen produced by the PSA device as 
follows: The effect of the flow rate on the purity of the oxygen produced by the PSA device is that if the flow rate is greater, the purity of oxygen obtained will be smaller. This is because the flow rate that is too large will cause the zeolite to decrease its ability to absorb gas faster because too much gas enters the tube so that too many molecules stick to the pores of the zeolite. The optimal flow rate to produce high oxygen purity for the PSA device used in this study is $20 \mathrm{~L} / \mathrm{min}$ for both types of adsorbents, resulting in an oxygen purity of $82 \%$ using Zeolite 13X. Meanwhile, with a mixture of Zeolite 13X and Zeolite Alam Bayah obtained a maximum purity of $73 \%$ with the same flow rate.

\section{REFERENCES}

[1] Sinha, P., \& Padhiyar, N. (2019). Optimal Startup Operation of A Pressure Swing Adsorption. IFAC Pap., 52(1), 130-135.

[2] Satria, D., Rosyadi, I., Lusiani, R., \& Listijorini, E. (2020). Design of machine element in alpha type stirling machine innovation design based on plastic waste. IOP Conf. Ser. Mater. Sci. Eng., 909 (1), 08. doi: 10.1088/1757-899X/909/1/012034.

[3] Jain, S., Moharir, A. S., Li, P., \& Wozny, G. (2003). Heuristic design of pressure swing adsorption: A preliminary study. Sep. Purif. Technol., 33 (1), 2543. doi: 10.1016/S1383-5866(02)00208-3.

[4] Gao, H., He, M., Sun, W., \& Yan, Y. (2018).Surface wave characteristic of falling film in swing absorber and its influences on abso rption performance. Appl. Therm. Eng., 129,1508-1517. doi: 10.1016/j.applthermaleng.2017.09.141.

[5] McCabe, W., Smith, J., \& Harriott, P. (2005). Unit Operations of Chemical Engineering. McGraw-Hill Education.

[6] Srihapsari, D. (2006). Penggunaan Zeolit Alam yang Telah Diaktivasi dengan Larutan $\mathrm{HCl}$ untuk Menjerap Logam-logam Penyebab Kesadahan Air. Universitas Negeri Semarang.

[7] Yuanita, L. D. (2010). Kajian Modifikasi dan Karakterisasi Zeolit Alam dari Berbagai Negara. Universitas Negeri Yogyakarta.

[8] Mulyanto, S., Suyitno, Rachmanto, R. A., Hidayat, L. L. G., Wibowo, A. H., \& S. Hadi. (2016). Synthesis and characterization of natural red dye from Caesalpinia sappan linn. AIP Conf. Proc., 1717, 17. doi: 10.1063/1.4943475.

[9] Warsito, S., Sriatun, \& Taslimah. (2008). Pengaruh Penambahan Surfaktan Cetylrimethylammonium Bromide (N-CTAB) pada Sintesis Zeolit-Y. Universitas Diponegoro.
[10] M. Mortimer, M., \& Taylor, P. (2002). Chemical Kinetics and Mechanism. Cambridge: The Royal Society of Chemistry.

[11] Ulfah, E. M., Yasnuar, F. A., \& Istadi. (2006). Optimasi Pembuatan Katalis Zeolit X dari Tawas, $\mathrm{NaOH}$ dan Water Glass dengan Response Surface Methodology. Universitas Diponegoro.

[12] Shokroo, E. J., Farsani, D. J., Meymandi, H. K., \& Yadollahi, N. (2016). Comparative study of zeolite $5 \mathrm{~A}$ and zeolite $13 \mathrm{X}$ in air separation by pressure swing adsorption. Korean J. Chem. Eng., 33(4), 1391-1401. doi: 10.1007/s11814-015-0232-6.

[13] Mofarahi, M., \& Shokroo, E. J. (2013). Comparison of two pressure swing adsorption processes for air separation using zeolite 5A and zeolite 13X. Pet. Coal, 55(3), 216-225.

[14] Hamed, H. H. (2015). Oxygen and Nitrogen Separation from Air Using Zeolite Type 5A. Al-Qadisiyah J. Eng. Sci., 8(2), 147-158.

[15] Satria, D., et al. (2019). Pengaruh Waktu Tahan Proses Pack Carburizing Baja AISI 3115 dengan Menggunakan Calcium Carbonat dan Batubara Sub Bituminous dan Mendapatkan Perlakuan Panas Quenching Media Pendingin Air. Rotasi, 21(2), 88. doi: 10.14710/rotasi.21.2.88-95.

[16] Satria, D., Susilo, S., Lusiani, R., \& Hermawan, Y. (2019). Design of alpha type stirling machine biomass-based innovation design with the capacity of 100 watt. IOP Conf. Ser. Mater. Sci. Eng., 673(1). doi: 10.1088/1757-899X/673/1/012124.

[17] Mistar, E., Sara, T., \& Alfata, T. (2017). Pengaruh Laju Alir Terhadap Kinetika Adsorpsi Methylene Blue dengan Karbon Aktif Tempurung Kelapa Teraktivasi NaOH. J. Serambi Eng., 1(2). 